\title{
An Overview of Indian Forestry Sector with REDD+ Approach
}

\author{
Vandana Sharma and Smita Chaudhry \\ Institute of Environmental Studies, Kurukshetra University, Kurukshetra 136119, Haryana, India \\ Correspondence should be addressed to Smita Chaudhry; smitachaudhryll@gmail.com
}

Received 27 May 2013; Accepted 29 June 2013

Academic Editors: K. Kielland and G. Martinez Pastur

Copyright (C) 2013 V. Sharma and S. Chaudhry. This is an open access article distributed under the Creative Commons Attribution License, which permits unrestricted use, distribution, and reproduction in any medium, provided the original work is properly cited.

\begin{abstract}
Forest ecosystems cover large parts of the terrestrial land surface and are major components of the terrestrial carbon (C) cycle. The primary objective of REDD+ is to minimize the carbon emissions from deforestation in developing countries and enhance their carbon storage capacities through sustainable management programme. The recognition of REDD+ throughout the international community, its support by donors and promotion in the perspectives of the UNFCCC negotiations are mainly due to vital functions of forests in regulating the world's climate. This paper gives an overview of REDD+ approach and its methodological guidance in context of Indian forestry sector. The strengthening of governance arrangements and institutions in India needs to integrate learning through piloting, adaptive management, and knowledge transfer. A phased approach for India for REDD+ implementation having safeguards for local communities and biodiversity along with a system of their reporting and capacity building has to be developed. Successfully designed REDD+ implementation in India entirely depends on a rigid, scalable, and reliable finance mechanism, technological assistance, and effective forest-related legislation along with transparent and equitable political momentum which has support of core stakeholder groups.
\end{abstract}

\section{Introduction}

Forests, like other ecosystems, are affected by climate change. Forests also influence climate, absorbing $\mathrm{CO}_{2}$ from the atmosphere and storing carbon in wood, leaves, litter, roots, and soil. The carbon is released back into the atmosphere when forests are cleared or burnt. By acting as sinks, forests are considered to moderate global climate change [1]. Climate change is one of the most significant global challenges of our time, and addressing it requires the urgent formulation of comprehensive and effective policy responses [2]. Natural forests are more resilient to climate change and disturbances than plantations because of their genetic, taxonomic, and functional biodiversity. This resilience includes regeneration after fire, resistance to and recovery from pests and diseases, and adaptation to changes in radiation, temperature, and water availability (including those resulting from global climate change). While the genetic and taxonomic composition of forest ecosystems changes over time, natural forests will continue to take up and store carbon as long as there is adequate water and solar radiation for photosynthesis [3]. Forests play a major role in the global carbon (C) cycle because they store $80 \%$ of the global aboveground C of the vegetation and about $40 \%$ of the soil C and interact with atmospheric processes through the absorption and respiration of $\mathrm{CO}_{2}[4-8]$. Human activities such as fuel consumption and land-use change are the main causes of an increase in the atmospheric carbon dioxide concentration, which is generally recognized as a factor of climate change and global warming [9]. The Stern Review [10] highlighted that forest conservation, afforestation, reforestation, and sustainable forest management can provide up to $25 \%$ of emission reductions needed to effectively combat climate change and that curbing deforestation has the potential to offer significant emission reductions fairly quickly in a highly cost-effective manner. Reducing emissions from deforestation and forest degradation (REDD+) is a mechanism for providing financial rewards to countries that reduce carbon emissions caused by the loss and degradation of their forests. In concept, REDD resembles other Payment for Environmental Services (PES) programs; however, REDD emphasizes a reduction in deforestation and degradation rates from expected levels, also known as avoided deforestation and degradation [11].

India has a total land area of 329 million hectares [12] of which around $23.4 \%$, that is, 76.87 million hectares (Mha), is 
classified as the forestland with tree cover. More than $40 \%$ of the country's forests are degraded and understocked $[13,14]$; subsequently there is a large potential of REDD+ activities in the country. Hence an overview of REDD+ approach along with its methodological guidance is discussed in this article in context of Indian forestry sector.

\section{RED to REDD+: Evolution Since Its Conceptualization}

Fuelled by the continuing destruction of forests in developing countries, the aspired development and implementation of a REDD+ mechanism under the United Nations Framework Convention on Climate Change (UNFCCC) evolved into one of the major issues in the negotiations on a post-Kyoto agreement [15]. The concept of REDD was first introduced in its preliminary form at the climate change negotiations during the third meeting of the Conference of Parties to the UNFCCC (COP-3) in 1997 to enlist carbon services of forests under the Clean Development Mechanism (CDM) and account for emissions and removals from land use, land use change, and forestry (LULUCF) activities [16]. Reducing emissions from deforestation in developing countries was being discussed in the side events since COP9 of the UNFCCC in 2003 under the names of "Avoided Deforestation," "Compensated reduction," and so forth [17]. When the Kyoto Protocol came into force in 2005, it focused on reductions in emissions from technological projects. This expression was used for the first time in its shortened form RED (reducing emissions from deforestation) during the 11th UN Conference of Parties (COP-11) in Montreal (2005) by the Coalition for Rainforest Nations led by Papua New Guineanoting that deforestation was estimated to account for 12$15 \%$ of the overall greenhouse gas (GHG) emissions [18]. Well received at COP-11, the concept was further elaborated, expanded, and officially adopted during COP-13 in Bali, Indonesia, in 2007 in the form of REDD. The addition of "degradation" to this acronym was due to the observation that forest degradation in some developing countries was as threatening as deforestation (if not more) to the forest ecosystems. Following the debates during the 14th COP in Poznan, Poland, in 2008, it was decided that REDD should evolve to REDD+ to encompass all the initiatives that can increase the carbon absorption potential of forests.

The insertion of "+" on the acronym REDD is aimed at broadening its scope to include all operations associated with preservation, restoration, and sustainable management of forest ecosystems. The official definition of REDD+ as set by UNFCCC is "reducing emissions from deforestation and forest degradation in developing countries, and the role of conservation, sustainable management of forests, and enhancement of forest carbon stocks in developing countries" [19]. During COP-16 of UNFCCC in 2010 in Cancun, governments agreed to boost action to curb emissions from deforestation and forest degradation in developing countries with technological and financial support [17]. REDD+ attaches financial value to the carbon stocks stored in the forests and other incentives for developing countries by the developed countries to reduce emissions and invest in low carbon paths to sustainable development. It goes beyond deforestation and forest degradation and includes the role of conservation, sustainable management of forests, and enhancement of carbon stocks. COP-17 in November, 2011 at Durban, South Africa, produced a landmark decision to extend the Kyoto Protocol into the second commitment period. Pursuant to Cancun decision, important decisions on REDD+ were made, namely, decisions on systems for providing information on safeguards, modalities for forests reference (emission) levels, and REDD+ financing [20]. The primary goal of REDD+ is reduction of greenhouse gas emissions, consistent with the goal of the UNFCCC to achieve "stabilization of greenhouse gas concentrations in the atmosphere at a level that would prevent dangerous anthropogenic interference with the climate system." REDD+ is expected to bring much more than emission reductions, with a properly designed mechanism contributing to multiple benefits. Depending on the location and type of REDD+ activity, these benefits potentially include poverty alleviation, indigenous people's rights, improved community livelihoods, technology transfer, sustainable use of forests resources, and biodiversity conservation [21].

REDD+ is a complex instrument of governance. It is treated by many stakeholders as a payments for ecosystems services (PES) scheme $[22,23]$ which seeks to translate the process of carbon sequestration through arboreal photosynthesis into real financial incentives for ecosystems managers and in so doing to promote the conservation and sustainable management of natural habitats $[24,25]$. The implementation of REDD-plus requires forest-governance reforms through inclusive processes that build on existing forest-governance systems [26].

India has played an important role in REDD+ negotiations and has been instrumental in shaping the REDD+ mechanism by emphasising the role of conservation and sustainable forest management in mitigating carbon emissions [16].

\section{Green Facts of India: A Megadiverse Country}

The forests of India have long been an important part of its culture and a defining feature of its landscape [27]. India with a wide range of climate, geography, and culture is unique among biodiversity-rich nations and is known for its diverse forest ecosystems and megabiodiversity. It ranks as the 10th most forested nation in the world [28], with $23.4 \%$ (76.87 Mha) of its geographical area under forest and tree cover [1,29]. Out of 34 global biodiversity "hot spots," four are located in India, that is, Eastern Himalayas, North-east, Sundarbans, and Western Ghats [30]. India is one of the 17 megadiverse countries (MoEF). Fifteen biodiversity-rich areas of country covering an area of approximately $74000 \mathrm{~km}^{2}$ have been designated as biosphere reserve and four of them, namely Nilgiri, Nanda Devi, Sundarbans, and Gulf of Mannar, have been recognised by UNESCO underworld network of biospheres [31]. With only $2.4 \%$ of the land area, India accounts for 7 to 8 percent of the recorded species of the world [32]. This biodiversity is of immense economic, ecological, 
social, and cultural value. Approximately 275 million people in India (27\% of the total population) are known to live in the forest fringes and earn bulk of their livelihood from forests [33-36]. FSI defines forests as "all the lands, more than one hectare in area, with a tree canopy density of more than $10 \%$." Champion and Seth [37] classified India's forests into four major ecosystems groups, namely, tropical, subtropical, temperate, and alpine. These major groups are further divided into 16 types. Of the 16 forests types, tropical dry deciduous forests form the major percentage that is $38 \%$ of the forest cover in India.

3.1. Key Challenges to Indian Forestry Sector. India's economic growth in the last decade has raised several concerns in terms of its present and future resource demands for material and energy [38]. With $18 \%$ of global livestock population over $2.4 \%$ of world's geographic area and $17 \%$ of world's population rigorous biotic pressure being faced by Indian forests as only due to these forests, nearly $30 \%$ of fodder needs of the cattle population and $40 \%$ of domestic fuel wood needs of the people are being catered. The difference in demand and supply is also broadening for fuel wood, timber, and fodder. In Eastern and Northeastern India, forest degradation is mainly a result of shifting cultivation practices over an area about 1.2 Mha. The National Forest Commission had done a splendid task to conquer the issues forests are facing by recommending allocation of a minimum $2.5 \%$ of national budget to the forestry sector. Apprehensions over inadequate role of elected Panchayati Raj institutes vis-a-vis Joint Forest Management Committees (JFMCs) in forest management, limited participation of non-profit-making voluntary sector, control over minor forest products, and implementation of Forest Right Act and PESA are some concerns frequently voiced with little recognition for the incredible efforts made to maintain forest cover in the current conflicting scenarios [31]. As per the wood budget for the year 1996, 86 million tonnes of fuel wood is being unsustainably removed from forests [39]. India's livestock population of 467 million grazes on 11 Mha of pastures. This implies that an average of 42 animals graze on a hectare of land compared to a threshold level of 5 [40]. In absence of adequate grazing land, nearly a third of the fodder requirement is met from the forest resources in the form of grazing and cut fodder for stall feeding. An estimated 100 million cow units graze in forests annually whereas the sustainable level is only 31 million [41]. Additionally, graziers collect an estimated 175-200 million tonnes of green fodder annually [42]. Grazing has been reported in $67 \%$ of the national parks and $83 \%$ of the wildlife sanctuaries surveyed $[40,43]$.

3.2. Deforestation. Around 3000 B.C, nearly $80 \%$ of India was forested [44, 45]. Deforestation has occurred in the tropics throughout history [46, 47]. Growing population, widespread poverty, and limited employment opportunities in agricultural and industrial sector have resulted in heavy pressure on forests, primarily due to unsustainable extraction of fuel wood and over grazing resulting in forest degradation [48]. Forest vegetation sequesters carbon while at the same time deforestation and degradation of standing forests leads
TABLE 1: Area under different legal categories of forest in India during 1946-47 [36, 52].

\begin{tabular}{lcc}
\hline Legal status & Area (million ha) & \% of total area \\
\hline $\begin{array}{l}\text { Reserve forest } \\
\text { Protected forest and } \\
\text { unclassified forest }\end{array}$ & 25.32 & 96.79 \\
\hline Total & 0.84 & 3.21 \\
\hline
\end{tabular}

to release of stored carbon [49]. The total forest cover has been declining globally. It stood at 3.95 Mha or about $30 \%$ of the global land area in 2006. The gross deforestation rate is estimated to have declined between 2000 and 2005 compared to the decade of the 1990s, but it still amounted to a gross and net loss of 12.9 and 7.3 Mha/year, respectively [50]. Deforestation refers to conversion of area having forest cover to other uses, for example, croplands, pastures, or urban land. Degradation [51], on the other hand, refers to reduction in productivity and/or diversity of a forest due to unsustainable harvesting (removals exceeding replacements and changes in species composition), fire (except for fire-dependent forest systems), pests and diseases, removal of nutrients, and pollution or climate change (e.g., changes in productivity, total organic matter, and forest composition). In India, the forest cover is now relatively stable and, therefore, deforestation is not currently a significant issue in formulation of carbon sequestration policies [40].

3.3. Stabilization of Carbon Stocks in Indian Forests. India recognized the enormous importance of the forest resources and land use, land-use change, and forestry (LULUCF) activities in contributing towards GHG emissions. Strong policy skeleton in India made the conservation of forests more focused [17]. The forestry sector recognizes its increasing role to provide sustained benefits to the people and strives to attain it by integrating new frontiers of knowledge and science in planning, management, research and capacity building with forest management [31]. A major part of forest land at the time of independence came under reserved forests [21]. During 1952-1976, forests were recognized only for the commercial interest, (Table 1), that is, for eradication of valuable timber for fast growth of industrial sector, nation's development and other purposes [36, 52].

Table 2 presents the change in forest cover over the years 1987 to 2011 indicating that the forest cover has increased marginally from 64.08 million ha in 1987 to 69.2 million ha in 2011.

India is one of the few countries where deforestation rates have been reduced and regulated and forest cover has nearly stabilised, unlike most other developing countries [28]. Thus it is important to understand the likely factors contributing to the observed stabilization of forest carbon stocks in India. The factors include legislations, forest conservation and afforestation programmes, and community awareness and participation [64]. Realizing the need for conservation and regeneration, several programmes have been implemented at the government and nongovernment levels. The forest policy 
TABLe 2: Profile of forests in India from 1987 to 2011 [29, 53-63].

\begin{tabular}{ccccccccccc}
\hline & \multicolumn{3}{c}{ Recorded forest area (in Mha) } & \multicolumn{3}{c}{ Forest cover (in Mha) } \\
Year & $\begin{array}{c}\text { Reserved } \\
\text { forests }\end{array}$ & $\begin{array}{c}\text { Protected } \\
\text { forests }\end{array}$ & $\begin{array}{c}\text { Unclassed } \\
\text { forests }\end{array}$ & $\begin{array}{c}\text { Total forests } \\
\text { area }\end{array}$ & $\begin{array}{c}\text { \% of } \\
\text { geographical } \\
\text { area }\end{array}$ & $\begin{array}{c}\text { Dense } \\
\text { forests }\end{array}$ & $\begin{array}{c}\text { Open } \\
\text { forests }\end{array}$ & $\begin{array}{c}\text { Mangroves } \\
\text { Total } \\
\text { geographical } \\
\text { area }\end{array}$ \\
\hline 1987 & 40.18 & 21.73 & 13.27 & 75.18 & 22.8 & 36.14 & 27.66 & 0.4 & 64.08 & 19.49 \\
1989 & 40.18 & 21.73 & 13.27 & 75.13 & 22.8 & 37.84 & 25.74 & 0.42 & 63.88 & 19.43 \\
1991 & 41.49 & 23.30 & 12.20 & 77.008 & 23.4 & 38.50 & 24.99 & 0.42 & 63.93 & 19.45 \\
1993 & 41.49 & 23.30 & 12.20 & 77.008 & 23.4 & 38.55 & 25.02 & 0.42 & 63.93 & 19.45 \\
1995 & 41.65 & 22.33 & 12.53 & 76.52 & 23.38 & 38.57 & 24.93 & 0.45 & 63.88 & 19.43 \\
1997 & 41.65 & 22.33 & 12.53 & 76.52 & 23.38 & 36.72 & 26.13 & 0.48 & 63.33 & 19.27 \\
1999 & 41.65 & 22.33 & 12.53 & 76.52 & 23.38 & 37.73 & 25.50 & 0.48 & 63.72 & 19.39 \\
2001 & 42.33 & 21.72 & 12.78 & 76.84 & 23.38 & 41.68 & 25.87 & 0.45 & 67.55 & 20.55 \\
2003 & 39.99 & 23.84 & 13.63 & 77.47 & 23.57 & 39.05 & 28.77 & 0.44 & 67.83 & 20.64 \\
2009 & 43.05 & 20.62 & 13.27 & 76.95 & 23.41 & 40.25 & 28.84 & 0.46 & 69.09 & 21.02 \\
2011 & 42.25 & 21.39 & 13.30 & 76.95 & 23.81 & 40.42 & 28.78 & 0.46 & 69.20 & 21.05 \\
\hline
\end{tabular}

in India was first introduced in colonial period, and later on changes were made in postcolonial period.

The few important acts, instruments, and rules governing the protection and conservation of forests include The Indian Forest Act, 1927; National Forest Policy, 1952; The Indian Wildlife (Protection) Act, 1972, amended in 1993; Forest (Conservation) Act, 1980, amended in 1988; Forest (Conservation) Rules, 1981, amended in 1992; The National Forest Policy, 1988; Joint Forest Management (JFM), 1990; Biological Diversity Act, 2002; Forest (Conservation) Rules, 2003; Biological Diversity Rules, 2004; and National Environment Policy, 2006. Of these, major contributory acts which majorly caused the stabilization of Indian forest cover are the following.

(i) Forest (Conservation) Act, 1980, amended 1988: this act is one of the most effective pieces of legislation contributing to reduction in deforestation. This was enacted to reduce the discriminate diversion of forest land for nonforestry purposes and to help regulate and control the land-use changes in the existing forest area. With this act, the deforestation and conversion of forest lands to nonforest use were effectively checked [64]. The rate of conversion of forests to nonforestry uses has declined drastically to around 15,500 ha per annum since 1980 compared to $1,50,000$ ha per annum prior to 1980 [42]. This act stipulates prior central government approval before any forest land is sought to be diverted for nonforestry purpose [40].

(ii) The National Forest Policy, 1988: India's National Forest Policy was formulated four years before the Earth Summit and embodies all elements-social, environment, and economic-of sustainable forest management. Its aim was to ensure environmental stability and maintenance of ecological balance, including atmospheric equilibrium, which is vital for sustenance of all life forms-humans, animals, and plants [16]. (iii) Joint Forest Management (JFM), 1990: The Forest Policy 1988 set the stage for participatory forest management in India. The JFM programme documented the rights of the protecting communities over forests lands. The local communities and the forest department together plan and implement forest recognition programmes and the communities are rewarded for their efforts in protection and management. The total area covered under JFM programme is over $15 \mathrm{Mha}$. This has allowed protection of forests plantation, potentially contributing to conservation of existing forests and carbon stocks [64].

3.4. Forest Degradation. Forest degradation is a complex process, and its drivers may be completely different from those for deforestation, thus presenting greater challenges in assessment or monitoring as compared to deforestation [65]. Widespread forest degradation in the developing countries remains poorly understood or quantified [66]. Change in forest composition because of selective overexploitation, loss of natural regeneration, low growing stock, and low productivity are important parameters resulting in low carbon content in the existing forests [40]. Shifting cultivation, fires, and overgrazing have resulted in the elimination of susceptible species and in making selected tolerant species more abundant [51]. The dynamics and causes of deforestation and forest degradation are multifaceted and complex and vary from place to place.

Drivers of deforestation and forest degradation in Indian perspective fall into two categories: first, who those are planned and projected in accordance with policies, legal framework, management plans, and so forth, and second, those who are spontaneous, beyond government and management control, and usually not accounted for. Planned and unplanned withdrawals from forests require proper understanding and management tools including transparent governance, effective enforcement, and appropriate mitigation actions [67]. The distinction between direct and underlying 
causes and between human- and naturally induced change is often not as clear as it might appear. In reality, there are long, complex chains of causation that can bring about deforestation or the degradation of forests [68].

If appropriate policy instruments and management options including effective legal framework and site specific mitigation measures are introduced then the impacts of planned or controlled drivers could be minimized. Challenge lies in addressing and managing unplanned drivers and activities which are mainly a direct outcome of local people's dependence on the adjoining forest areas to meet their livelihood needs like necessity of fuel wood, fodder, grazing, food supplements, and to a very small extent an illegal mining within forest and so forth [67]. Forest productivity is the net annual increment per unit forest area. The productivity of Indian forests is low [40]. The growing stock of forests area is estimated to be around $58.96 \mathrm{~m}^{3} \mathrm{ha}^{-1}$ in ISFR for the year 2009 and 2011, which is far lower when compared to the global average of $130.7 \mathrm{~m}^{3} \mathrm{ha}^{-1}$ and South and Southeast Asian average of $98.6 \mathrm{~m}^{3} \mathrm{ha}^{-1}$ for the corresponding period [69, 70]. The National Forest Commission report 2006 indicated that around 41 per cent of total forest in the country is already degraded, 70 percent of the forests have no natural regeneration, and 55 per cent of the forests are prone to fire [71]. As per the study of Nayak et al. [70] the factors affecting forest degradation in India mainly include critical livelihood, demand and supply gap of forests products, forests fires, overgrazing, illegal felling, and diversion of forest land for nonforest uses due to competing land-use demand for development and so forth [13, 61, 63, 71-73].

3.5. Forest Degradation and Deforestation: Addressal Mechanism. Reserving forests implies foregoing the benefits that would have been generated by exploiting the resources or from adopting alternative land-use practices. Further, the onsite benefits of forests are lower than the potential benefits of alternative land uses [16]. The strategies and approaches to evolve a mechanism to tackle forest degradation and deforestation will be critical to attain the maximum benefits of incentives for the stored carbon stocks. Creation of appropriate awareness amongst stakeholders in deciding the level of their participation and commitment including that of the local community for protection of existing forests might be the leading action for checking deforestation and forest degradation. The stakeholders need to be effectively and appropriately informed, enthused, and empowered to take apt decision for conservation of forests. This should be supported by the government programmes and policies, which should advocate and provide the relevant alternative resources to the community so that the dependence of local community on forest resources could be reduced. As per Indian submission to SUBSTA, UNFCCC, these programmes could include

(i) alternative cheap cooking fuel supply,

(ii) promoting non-conventional energy sources,

(iii) low-cost permanent housing facilities,

(iv) improving agriculture and livestock productivity,

(v) free education for children, (vi) better infrastructural facilities including health,

(vii) effective use of modern communication audiovideo tools for creating awareness among community.

Striking a balance between the need to enhance food production for growing population and to cut short deforestation requires increase in agricultural production without further deforestation. This can be addressed through better land planning and extensive investment in technology to increase yields of existing farmlands [67].

\section{Safeguards for REDD+ Implementation}

Since 2009, the UNFCCC negotiations have increasingly taken up the concerns regarding potential negative effects of REDD+ on the biodiversity of forest ecosystems, safeguards and benefits being key words in this matter [15]. The implementation of REDD+ actions can pose a number of risks or negative impacts including conversion of natural forests to plantations and other land uses of low biodiversity, loss of traditional territories, erosion of rights with exclusion from land, and loss of traditional livelihoods [74]. At COP17 in Durban (Decision 12/CP.17 Para 5) it was agreed that a summary of information on how safeguards are being addressed and respected should be provided periodically in national communication channels agreed on by the COP [16].

The new term safeguards was introduced during AWGLCA intersessions (Bonn, August 2009): “... [safeguards to protect biological diversity in host countries, including safeguards against conversion of natural forests to forest plantations, should be established]." The underlying principle behind this was to deal with the dilemma of not having a mandate to explicitly include biodiversity and the simultaneous need to ensure that REDD would not create incentives that could offset the biodiversity objectives of the CBD. In later AWGLCA negotiations cobenefits were replaced by safeguards (nonpaper 18 and 39, FCCC/AWGLCA/2009/L.7/Add.6). At COP15 the text on this matter reads and "... the following safeguards should be [promoted] [and] [supported] (e) Actions that are consistent with the conservation of natural forests and biological diversity, ensuring that actions [...] are not used for the conversion of natural forests, but are instead used to incentivize the protection and conservation of natural forests and their ecosystem services, and to enhance other social and environmental benefits" [15].

In many REDD+ countries, discussions on safeguards are in their infancy and represent only a minor component of the overall REDD+ policy dialogue [75]. Safeguards can be most effectively addressed if explicit consideration is given to biodiversity concerns during all of the planning and design, implementation, and assessment stages of the REDD+ process [76]. The REDD+ framework that is part of Cancun Agreements includes a number of safeguard provisions that are to be addressed and respected throughout the implementation of REDD+ activities [17]. The UNFCCC, in the Cancun Agreement, articulated seven social and environmental safeguards for REDD+ [77]. These are 
(1) actions that complement or are consistent with the objectives of national forest programmes and relevant international conventions and agreements;

(2) transparent and effective national forest governance structures, taking into account national legislation and sovereignty;

(3) respect for the knowledge and rights of indigenous peoples and members of local communities, by taking into account relevant international obligations, national circumstances and laws, and noting that the United Nations General Assembly has adopted the UN Declaration on the Rights of Indigenous Peoples;

(4) the full and effective participation of relevant stakeholders, in particular indigenous peoples and local communities;

(5) actions that are consistent with the conservation of natural forests and biological diversity, ensuring that actions referred to in paragraph 70 of this decision are not used for the conversion of natural forests but are instead used to incentivize the protection and conservation of natural forests and their ecosystem services and to enhance other social and environmental benefits;

(6) actions to address the risk of reversals;

(7) actions to reduce the displacement of emissions.

The Subsidiary Body for Scientific and Technical Advice (SBSTA) has been tasked with providing guidance on systems for information on how REDD safeguards are being addressed and respected throughout the implementation of REDD+ [78]. Implementation of safeguards should be country based and not imposed externally. Safeguards need to be flexible and reflect national status and not formulated as additionality [17]. Free, prior, and informed consent (FPIC) could be an important element of REDD+ safeguard programs, ensuring that activities are implemented in a way that fully respects the rights of affected communities $[21,79]$.

In order to effectively monitor safeguards in India, it will be necessary to evolve a clearly defined set of indicators and criteria for parameters such as forest governance structures, respect for rights of indigenous peoples, and full and effective participation of relevant stakeholders, along with a system to monitor these $[20,29]$. India has well-established forest governance system, responsible for forest management as per the Indian government policy, legal institutions, and regulatory framework. The governance system impounds the dynamism of forest behaviour. The management of forests gets inputs from the various local, regional, and national level bodies, constituting with members from the local villages. In India, there are safeguards already in place to protect the customary rights and traditions of tribes, forest dwellers, and other local communities. Policy and legal instruments exist in the form of joint management programmes, the Forest Rights Act, and the Biological Diversity Act, whose provisions ensure the rights of local communities and enable them to be key players in the local level governance of the natural resources [16].

\section{Developing MRV System for REDD+}

Transparent, accountable, and sustainable monitoring, reporting, and verification (MRV) systems are essential for any REDD+ framework. With the prospect of a global agreement on forest preservation on the horizon, establishing functional MRV systems is one of the major goals of the so-called REDD Readiness [80]. MRV relates to both actions on the ground (i.e., that change forest carbon stocks) and REDD+ transactions (i.e., compensation and financial transactions or transfers) [81]. A robust monitoring mechanism is essential for successful implementation. As part of the Cancun Agreement, countries are supposed to develop a robust and transparent national forest-monitoring system with the capacity to consistently and accurately monitor changes in forest cover and carbon stocks over time. There is a general consensus that this forest monitoring system would be a combination of remote sensing and ground-based systems [20,65]. Any system that intends to compensate countries for avoided deforestation and degradation requires a reference level for recent forest carbon stocks against which future performance can be measured. The choice of reference level will determine not only the effectiveness of REDD+ in terms of climate impact, but also the potential financial benefits to recipients of REDD+ funding and hence incentives for countries to participate in the scheme $[82,83]$.

India is among the few countries to regularly use satellitebased remote sensing technology since the 1980s in detecting and assessing forest cover changes [63]. Under the second National Communication to UNFCCC, forest biomass carbon and soil organic carbon were estimated in India, and the procedure which was followed for the programme has the potential of being developed and adopted as a REDD+ methodology for assessing changes in forest carbon stocks over a stipulated period [17]. India is of the view that the reference level (RL)/reference emission level (REL) needs to be fixed in an open and transparent manner following the procedure decided by the parties for the purpose [16]. India will have to develop a robust system for monitoring of carbon stocks in forests through a network of permanent monitoring plots to provide adequately accurate subnational estimates of carbon stock changes [20].

The Government of India formally adopted Communitybased Forestry Management/Joint Forest Management resolution on July 1, 1990, in pursuance of its National Forest Policy, 1988. It laid down broad guidelines for an institutional arrangement involving the local people to jointly protect and manage the forest resources in return for benefits from it [40]. Joint forest management (JFM) has facilitated protection and regeneration of existing forests and rise of forest plantations, which will contribute to conservation of existing forests as also the carbon stocks. This approach matches well with the objectives of REDD+ programmes being implemented in many REDD+ countries [17].

\section{Financing of REDD+ Mechanism}

Essentially, REDD+ is an investment focusing on retaining or enhancing natural capital and provides an opportunity 
to enable countries to move towards realizing green development [84]. Multilateral, bilateral, and private funding mechanisms are now supporting different REDD+ activities at various levels. Multilateral mechanisms like UN-REDD programme, World Banks' Forest Caron Partnership Facility (FCPF), and Forest Investment Programme (FIP) are supporting capacity building activities in many developing countries for the effective implementation of REDD+ [85]. REDD+ investments are focused on maintaining or enhancing natural capital, either through investments in forests or through slowing, halting, or reversing drivers of deforestation and forest degradation [84]. REDD+ finance mechanism must be effective: they must contribute to tangible and independent third-party-verifiable stabilizations of atmospheric concentrations of greenhouse gases; efficient: they must result in "value for money" and allow both private-sector and public-sector institutions to participate on fair terms; and equitable: at a minimum, they must avoid exposing to greater risk the poor and most marginalized rural communities whose livelihoods depend on forests, avert the distortion of forest products markets, and allow broad participation on equitable terms at the national and international levels [26].

India supports a mix of market and global funds to finance REDD+ activities. Central funding should compensate for maintenance of forest carbon stocks whereas money for compensating change in carbon stocks (due to decrease in deforestation and degradation or increase in forest cover) could be generated by selling carbon credits in the international markets $[73,85]$. Separate financial approaches need to be adopted for providing positive incentives for the two types of carbon stocks under REDD+ regime, that is, for (a) change in carbon stocks (with subcategories for incremental carbon stocks and reduced deforestation) and (b) baseline carbon stocks [17]. The market-based approaches that would be developed for incentivizing removals and emission reductions to be separate from the CDM market and conservation of forest carbon stocks could be incentivized through non-market-based mechanisms [16]. Any REDD finance mechanism-market-based or fund based-needs to properly address the concepts of carbon stock and flow, uncertainty, and discount rates [26].

6.1. Green India Mission. In the context of the overall objective of the National Action Plan on Climate Change (NAPCC), the environmental service which is of utmost importance, is the carbon sequestration potential of the forests. NAPCC correctly recognizes increase and improvement in forest and tree cover as a potential mitigation option. Indian initiative to have a "national mission for a green India" as one of the eight national missions is a very pragmatic step that fits most appropriately into the country's concern on climate change, as also into its overall developmental planning [86]. The government has put in place Green India Mission with a budget of Rs 46,000 crores (approximately USD 10 billion) over a period of 10 years. The mission will help in improving ecosystem services in 10 million ha of land and increase flow of forest-based livelihood services and income of about 3 million forest dependent households [27].
The GIM acknowledges the influence that the forestry sector has on environmental amelioration and inclusive development [87]. The Green India Mission puts the "greening" in the context of climate adaptation and mitigation, aiming to enhance ecosystem services like hydrological services and biodiversity, including carbon sequestration and storage (in forests and other ecosystems), in addition to provisioning services like fuel, fodder, timber, and NTFPs, while also addressing the livelihood issues of people living in and around forests [88]. In addition to other objectives, the mission will also seek positive incentives from REDD+ mechanism. The experience of implementing concept of JFM can successfully be replicated in protecting the rights of the tribal and other forest-dwelling communities while involving them in the proposed REDD+ mechanism. The mission is the practical demonstration of India's support for policy of conservation, sustainable management of forests and increase in forest cover as a means of reducing emissions from deforestation. However, achievement of incremental targets laid in the mission would not be possible fully unless the mission receives the supplemental financial support from the future REDD+ mechanism. Similarly, there is likelihood of financial support for maintenance of baseline stocks through REDD+ mechanism [86].

The Forest Carbon Partnership (FCPF) aims to prepare forest countries for REDD+ implementation-known as REDD+ Readiness [17]. The FCPF assists developing countries in their efforts to reduce emissions from deforestation and forest degradation and foster conservation, sustainable management of forests, and enhancement of forest carbon stocks (all activities commonly referred to as "REDD+") by providing value to standing forests. The Interim REDD+ Partnership created in Paris during the May 2010 conference on forests and climate change was made up of an initial group of six developed nations who have pledged to provide US $\$ 4.5$ billion to assist developing countries jumpstart REDD+ activities [19]. The Eliasch Review [89] estimated that the onetime cost requirements for 40 countries to reform policy and build capacity for REDD totalled US $\$ 4$ billion.

Whether REDD is financed through a voluntary fund, a market mechanism, a hybrid mechanism (e.g., revenues from permit auctions in a cap and trade system), or a combination thereof, it must generate finance at the appropriate scale and to the appropriate stakeholders and sustain it over time [90].

\section{REDD+ Strategy of India}

The REDD+ text in the Cancun Agreements has came out from the text that had been discussed for many years in the UNFCCC negotiations. The text sets the stage for a nationally driven phased approach to a REDD+ mechanism. The international framework involves a three-phase approach for an REDD+ mechanism for developing countries like India: (1) development of national strategies or action plans and capacity building; (2) implementation of national strategies or action plans that could involve REDD+ pilot projects; and (3) mobilization of funds from developed countries, with financing mechanisms [21]. 
The REDD+ strategy plan for India containing three phases is still under preparation. These phases are as follows

(i) Phase I: preparation for adoption of REDD+,

(ii) Phase II: understanding implementation of REDD+,

(iii) Phase III: full scale result-based implementation of REDD+.

The strategy will be implemented in a coherent and mutually supportive way with the relevant Aichi Biodiversity Targets (5, 7, 11, 14, and 15) and the Strategic Plan for Biodiversity 2011-2020 through various elements of REDD+. The REDD+ strategy plan for India will include mechanism for addressing direct benefit for biodiversity as well as benefit sharing to indigenous and local communities [91].

The incentives so received from REDD+ would be passed to the local communities involved in protection and management of the forests. This will ensure sustained protection of our forests against deforestation [27]. In Indian context, the forest will not be managed for "carbon services" alone, but for all the ecosystem services that are flowing from the forests to the local community. The incentives for carbon services will append to the benefits that the local communities are already receiving from the forest ecosystems [91]. It is estimated that a REDD+ programme for India could provide capture of more than 1 billion tonnes of additional $\mathrm{CO}_{2}$ over the next 30 years and provide more than USD 3 billion as carbon service incentives under REDD+ [27]. The country specific safeguards will be a part of national strategy with a view to ensure full participation of local communities and all other stakeholders. India's national REDD+ strategy aims to enhance the quantum of forest ecosystem services that flow to the local communities by enhancing and improving the forest and tree cover of the country [91].

Hitherto, India has not prepared a REDD+ strategy as required under the UNFCCC; hence a dedicated institutional structure needs to be put in place to formulate and implement a national REDD+ strategy with a clearly defined mandate, roles, and responsibilities [20]. The issues to be addressed through REDD+ are complex in nature. The implementation of REDD+ frameworks will be strongly influenced by the presence or lack of robust legal framework. The existence of a legal framework that addresses environmental, social and economic issues that reflect the international legal framework of norms and standards is crucial for India to adopt standards on REDD+ [74].

\section{Conclusion}

Currently, there is significant concern over global warming, green house gas emissions, and their possible impacts on society. For successful implementation of REDD+ in India, technological assistance, readiness assistance, and continued political momentum are essential. A fully fledged national REDD+ strategy needs to be developed and implemented along with action plans with an immediate start of pilot activities in selected areas in collaboration of partners at national and international levels. An enormous capacity building at every level of forest hierarchy is needed for successful REDD+ implementation. An appropriate multilateral financial mechanism needs to be developed to operationalize capacity building programmes. The urgency of national REDD+ institutional framework stems from the fact that the implementation of REDD+ will involve tremendous coordination efforts. Pilot projects for REDD+ can be initiated in joint forest management areas. For effective implementation of REDD+ programmes there is need for forests-related legislation in place to enable REDD+ related project development which also includes definitions of ownership, rights, and obligations with respect to the sale and trade of carbon or Payment for Environmental Services (PES) accrued through REDD+ projects.

\section{References}

[1] J. Kishwan, R. Pandey, and V. K. Dadhwal, "Emission removal capability of India's forest and tree cover," Small Scale Forestry, vol. 11, no. 1, pp. 61-72, 2012.

[2] C. Streck, R. Sullivan, S. J. Toby, and R. Tarasofsky, Eds., Climate Change and Forestry-Emerging Policy and Market Opportunities, Royal Institute of International Affairs, Brookings Institution Press, Baltimore, Md, USA, 2008.

[3] B. G. Mackey, H. Keith, S. L. Berry, and D. B. Lindenmayer, "Green Carbon-the role of natural forests in carbon storage, part 1-A green carbon account of Australia's South-Eastern eucalypt forest, and policy implications," in The Fenner School of Environment \& Society, The Australian National University E Press, Australia, 2008.

[4] S. L. Brown, P. Schroeder, and J. S. Kern, "Spatial distribution of biomass in forests of the eastern USA," Forest Ecology and Management, vol. 123, no. 1, pp. 81-90, 1999.

[5] J. T. Houghton, Y. Ding, and D. J. Griggs, Eds., Climate Change 2001: The Scientific Basis. Contribution of Working Group I to the Third Assessment Report of the Intergovernmental Panel on Climate Change, Cambridge University Press, Cambridge, UK, 2001.

[6] R. A. Houghton, K. T. Lawrence, J. L. Hackler, and S. Brown, "The spatial distribution of forest biomass in the Brazilian Amazon: a comparison of estimates," Global Change Biology, vol. 7, no. 7, pp. 731-746, 2001.

[7] C. L. Goodale and M. J. Apps, "Forest sinks in the Northern hemisphere," Ecology Applied, vol. 3, pp. 891-899, 2002.

[8] X. Zhang, M. Wang, and X. Liang, "Quantitative classification and carbon density of the forest vegetation in Lüliang Mountains of China," Plant Ecology, vol. 201, no. 1, pp. 1-9, 2009.

[9] Food Agriculture Organization, Carbon Sequestration in Dryland Soils, Food and Agriculture Organization of the United Nations, Rome, Italy, 2004.

[10] Sir Nicholas Stern, Stern Review: The Economics of Climate Change, Cambridge University Press, Cambridge, UK, 2006.

[11] H. J. Albers and E. J. Z. Robinson, "Reducing emissions from deforestation and forest degradation," Encyclopaedia of Energy, Natural Resources and Environmental Economics, vol. 2, pp. 7885, 2013.

[12] H. Gundimeda, P. Sukhdev, R. K. Sinha, and S. Sanyal, "Natural resource accounting for Indian states-illustrating the case of forest resources," Ecological Economics, vol. 61, no. 4, pp. 635649, 2007. 
[13] A. Aggarwal, V. Paul, and S. Das, Forest Resources: Degradation, Livelihoods, and Climate Change, Looking Back to Change Track, TERI, New Delhi, India, 2009.

[14] V. K. Bahuguna, K. Mitra, D. Capistrano, and S. Saigal, Root to Canopy: Regenerating Forests Through Community State Partnerships, Winrock International India, Commonwealth Forestry Association, New Delhi, India, 2004.

[15] T. Pistorius, C. B. Schmitt, D. Benick, and S. Entenmann, Greening REDD+: Challenges and Opportunities for Forest Biodiversity Conservation, University of Freiburg, Germany, 2010.

[16] R. Sud, J. V. Sharma, and A. K. Bansal, International REDD+ Architecture and Its Relevance for India, The Energy and Resources Institute (TERI), New Delhi, India, 2012.

[17] V. R. S. Rawat, "REDD Plus in India: from negotiations to implementation," in Proceedings of the Pre-Congress Workshop of 1st Indian Forests Congress, ICFRE, Dehradun, India, 2011.

[18] G. R. Van Der Werf, D. C. Morton, R. S. Defries et al., " $\mathrm{CO}_{2}$ emissions from forest loss," Nature Geoscience, vol. 2, no. 11, pp. 737-738, 2009.

[19] EDRI, From RED To REDD+, Africa Regional Dialogue on Forests, Governance \& Climate Change, 2010.

[20] N. H. Ravindranath, N. Srivastava, I. K. Murthy, S. Malaviya, M. Munsi, and N. Sharma, "Deforestation and forest degradation in India-implications for REDD+," Current Science, vol. 102, pp. 1117-1125, 2012.

[21] IISD, Safeguards and Multiple Benefits in a REDD+ Mechanism, International Institute of Sustainable Development, Canada, 2011, www.iisd.org.

[22] T. Clements, "Reduced expectations: the political and institutional challenges of REDD+," ORYX, vol. 44, no. 3, pp. 309-310, 2010.

[23] M. Collins, E. A. Macdonald, L. Clayton, I. Dunggio, D. W. Macdonald, and E. J. Milner-Gulland, "Wildlife conservation and reduced emissions from deforestation in a case study of Nantu Wildlife Reserve, Sulawesi: 2. An institutional framework for REDD implementation," Environmental Science and Policy, vol. 14, no. 6, pp. 709-718, 2011.

[24] S. Engel, S. Pagiola, and S. Wunder, "Designing payments for environmental services in theory and practice: an overview of the issues," Ecological Economics, vol. 65, no. 4, pp. 663-674, 2008.

[25] C. McDermott, REDD+ Biodiversity Safeguards: Strength in Diversity-A Study of the Capacity of the UNFCCC to Deliver Equitable, Effective, and Efficient Forest Conservation Policies for Developing Countries, Oxford University School of Geography and the Environment, 2011, Candidate Number: 53172.

[26] The Forests Dialogue, Investing in REDD-Plus Consensus Recommendations on Frameworks For the Financing and Implementation of REDD-Plus, TFD Review, A TFD Publication, 2010, www.theforestsdialogue.org.

[27] Ministry of Environment and Forests, India's Forests and REDD+, Ministry of Environment and Forests, Government of India.

[28] "Global Forest Resources Assessment 2005: Progress towards Sustainable Forest management," FAO Forestry Paper 147, Food and Agriculture Organization of the United Nations, Rome, Italy, 2006.

[29] State of Forest Report, Forest Survey of India, Dehradun, India, 2009.

[30] B. Pisupati, Safeguarding India's Biological Diversity: The Biological Diversity Act, Farmer's Forum, India’s Agriculture Magazine, 2011.
[31] ICFRE, Indian Forest Congress, Ministry of Environment and Forests, 2011, http://ify-india.icfre.gov.in/indiaforest.html.

[32] Y. Gokhale, Cover Story, Terragreen Magzine, 2010.

[33] World Bank, "New global poverty estimates in India," World Bank, 2001, http://www.worldbank.org.in/wbsite/external/ countries/southasiaext/indiaextn/0,menupk:295589 pagepk: 141159 pipk:141110 thesitepk:295584,00.html.

[34] M. Poffenberger, Community and Forest Management in South Asia-A Regional Profile of the Working Group on Community Involvement in Forest Management, Forest, people and policies, IUCN, Switzerland, 2000.

[35] World Bank, "An article of World Bank on India: Alleviating Poverty through Forest Development," 2006, World Bank, http://www.worldbank.org/ieg).

[36] B. Sinha, C. P. Kala, and A. S. Katiyar, Enhancing Livelihoods of Forest Dependent Communities Through Synergizing FDA Activities with Other Development Programmes, Indian Institute of Forest Management, Bhopal, India, 2010.

[37] H. G. Champion and V. K. Seth, A Revised Survey of the Forest, Types of India, Government of India, 1968.

[38] S. J. Singh, F. Krausmann, S. Gingrich et al., "India’s biophysical economy, 1961-2008. Sustainability in a national and global context," Ecological Economics, vol. 76, pp. 60-69, 2012.

[39] Forest Survey of India, Demand and Supply of Fuelwood, Timber and Fodder in India, Forest Survey of India, Dehradun, India, 1996.

[40] P. P. Singh, "Exploring biodiversity and climate change benefits of community-based forest management," Global Environmental Change, vol. 18, no. 3, pp. 468-478, 2008.

[41] R. Pachauri and R. K. Batra, Eds., Directions, Innovations, and Strategies for Harnessing Action for Sustainable Development, Tata Energy Research Institute, New Delhi, India, 2001.

[42] National Forestry Action Plan, Ministry of Environment and Forest, Government of India, New Delhi, India, 1999.

[43] S. Singh, India: Assessing Management Effectiveness of Wildlife Protected Areas in India, 2001, http://www.iucu.org/ themes/forests/protected area/India.pdf.

[44] T. N. Khushoo, Environmental Priorities in India and Sustainable Development, Indian Science Congress, Calcutta, India, 1986.

[45] F. Warner, Indo Swedish Forestry Programme II: 1982-83 TO, 1986-87, Background Document, Swedish Embassy Dev Cooperation office, New Delhi, India, 1982.

[46] J. F. Richards, "Global patterns of land conversion," Environment, vol. 26, no. 9, pp. 6-34, 1984.

[47] M. Williams, Forests: The Earth as Transformed by Human Actions, Cambridge University Press, Cambridge, UK,, 1990.

[48] M. Joshi and P. P. Singh, Tropical Deforestation and Forest Degradation: A Case Study from India, XII World Forestry Congress, Quebac City, Canada, 2003.

[49] J. Sathaye, K. Andrasko, and P. Chan, "Emissions scenarios, costs, and implementation considerations of REDD-plus programs," Environment and Development Economics, vol. 16, no. 4, pp. 361-380, 2011.

[50] Food Agriculture Organization, State of the World's Forests, Food and Agriculture Organization of the United Nations, Rome, Italy, 2007.

[51] TERI, Looking Back to Think Ahead: GREEN India 2047, Tata Energy Research Institute, New Delhi, India, 1998.

[52] N. H. Ravindranath, R. K. Chaturvedi, and I. K. Murthy, "Forest conservation, afforestation and reforestation in India: 
Implications for forest carbon stocks," Current Science, vol. 95, no. 2, pp. 216-222, 2008.

[53] State of Forest Report, Forest Survey of India, Dehradun, 1987.

[54] State of Forest Report, Forest Survey of India, Dehradun, 1989.

[55] State of Forest Report, Forest Survey of India, Dehradun, 1991.

[56] State of Forest Report, Forest Survey of India, Dehradun, 1993.

[57] State of Forest Report, Forest Survey of India, Dehradun, 1995.

[58] State of Forest Report, Forest Survey of India, Dehradun, 1997.

[59] State of Forest Report, Forest Survey of India, Dehradun, 1999.

[60] State of Forest Report, Forest Survey of India, Dehradun, 2001.

[61] State of Forest Report, Forest Survey of India, Dehradun, 2003.

[62] State of Forest Report, Forest Survey of India, Dehradun, 2005.

[63] State of Forest Report, Forest Survey of India, Dehradun, 2011.

[64] D. M. Bhat, K. S. Murali, and N. H. Ravindranath, "Formation and recovery of secondary forests in India: a particular reference to Western Ghats in South India," Journal of Tropical Forest Science, vol. 13, no. 4, pp. 601-620, 2001.

[65] S. Bajracharya, Community carbon forestry: remote sensing of forest carbon and forest degradation in Nepal [M.S. thesis], International Institute for Geo-information Science and Earth Observation, Enscheda, The Netherlands, 2008.

[66] J. O. Niles, S. Brown, J. Pretty, A. Ball, and J. Fay, Potential Mitigation and Income in Developing Countries from Changes in Use and Management of Agricultural and Forest Lands, Center of Environment and Society, Occasional, University of Essex, 2001.

[67] United Nations Framework Convention on Climate Change, Submission by India to SBSTA, UNFCCC on Agenda Item 4: Methodological guidance for activities relating to reducing emissions from deforestation and forest degradation and the role of conservation, sustainable management of forests and enhancement of forests carbon stocks in developing countries (UNFCCC Document FCCC/SBSTA/L. 25 dated 3 Dec 2011), 2011.

[68] United Nations Framework Convention on Climate Change, The Cancun Agreements: Outcome of the work on the Ad Hoc Working Group on Long-Term Cooperative Action under the Convention. Report of the Conference of the parties on its sixteenth session, held in Cancun from November 29December 10, 2010. FCCC/CP/2010/7/Add. 1., 2011.

[69] Food Agriculture Organization, "Global Forest Resource Assessment 2010,” FAO Forestry Paper 163, Rome, Italy, 2010.

[70] B. P. Nayak, P. Kohli, and J. V. Sharma, Livelihood of Local Communities and Forest Degradation in India: Issues For REDD+, The Energy and Resources Institute, New Delhi, India, 2012.

[71] Ministry of Environment and Forests, Report of the National Forest Commission, Ministry of Environment and Forests, Government of India, New Delhi, India, 2006.

[72] P. Davidar, S. Sahoo, P. C. Mammen et al., "Assessing the extent and causes of forest degradation in India: where do we stand?" Biological Conservation, vol. 143, no. 12, pp. 2937-2944, 2010.

[73] Ministry of Environment and Forests, "Asia-pacific forestry sector outlook study II: India country report," Working Paper APFSOS II/WP/2009/06, FAO, Bangkok, Thailand, 2009.

[74] N. Moss, R. Nussbaum, and J. Muchemi, REDD+ SafeguardsBackground Paper Prepared For REDD+ Partnership, Workshop on Enhancing Coordinated Delivery of REDD+: Emerging Lessons, Best Practices and Challenges, Cancún, Mexico, 2010.

[75] D. M. Mwayafu and J. W. Kisekka, Promoting and Implementing REDD+ Safeguards at National Level in East Africa, REDD-net programme, Norwegian Agency for Development Cooperation (NORAD), 2012.

[76] T. A. Gardner, N. D. Burgess, N. Aguilar-Amuchastegui et al., "A framework for integrating biodiversity concerns into national REDD+ programmes," Biological Conservation, vol. 154, pp. 6171, 2012.

[77] United Nations Framework Convention on Climate Change, The Cancun Agreements 1/CP. 16., 2010.

[78] Greenpeace, REDD: A Common Approach to Safeguards, 2011.

[79] United Nations Commission on Human Rights, "SubCommission on the Promotion and Protection of Human Rights," in Proceedings of the 22nd session Working Group on Indigenous Populations, New York, NY, USA, 2004.

[80] B. Palmer Fry, "Community forest monitoring in REDD+: the 'M' in MRV?" Environmental Science and Policy, vol. 14, no. 2, pp. 181-187, 2011.

[81] A. Angelsen, Realising REDD+: National Strategy and Policy Options, Centre for International Forestry Research (CIFOR), Bogor, Indonesia, 2009.

[82] A. Angelsen, S. Brown, C. Loisel, L. Peskett, C. Streck, and D. Zarin, Reducing Emissions from Deforestation and Forest Degradation (REDD): An Options Assessment Report, Meridian Institute, Washington, DC, USA, 2009.

[83] E. Mattsson, U. M. Persson, M. Ostwald, and S. P. Nissanka, "REDD+ readiness implications for Sri Lanka in terms of reducing deforestation," Journal of Environmental Management, vol. 100, pp. 20-40, 2012.

[84] P. Sukhdev, R. Prabhu, P. Kumar et al., REDD+ and a Green Economy: Opportunities for a mutually Supportive relAtionship, UN-REDD Programme Policy Brief, 2012.

[85] A. Aggarwal, "Implementation of forest rights act, changing forest landscape, and politics of REDD+ in India," Resources, Energy, and Development, vol. 8, no. 2, pp. 131-148, 2011.

[86] Chapter on Climate Change and Forests, Ministry of Environment and Forests, Government of India.

[87] Planning Commission, Interim Report of the Expert Group on Low Carbon Strategies for Inclusive Growth, Government of India, 2011.

[88] National Action Plan on Climate Change, Prime Minister's Council on Climate Change, Government of India, undated, http://pmindia.nic.in/Pg01-52.pdf.

[89] J. Eliasch, Climate Change: Financing Global Forests, Office of Climate Change, 2008, http://www.illegal-logging.info/ sites/default/files/uploads/Fullreporteliaschreviewl.pdf.

[90] C. A. Harvey, B. Dickson, and C. Kormos, "Opportunities for achieving biodiversity conservation through REDD," in Conservation Letters, pp. 1-9, Wiley Periodicals, 2009.

[91] United Nations Framework Convention on Climate Change, Inputs of Climate change Division on Agenda Item 7 of SUBSIDIARY BODY ON SCIENTIFIC, TECHNICAL AND TECHNOLOGICAL ADVICE for Sixteenth meeting at Montreal, 30 April 5 May 2012, 2012. 

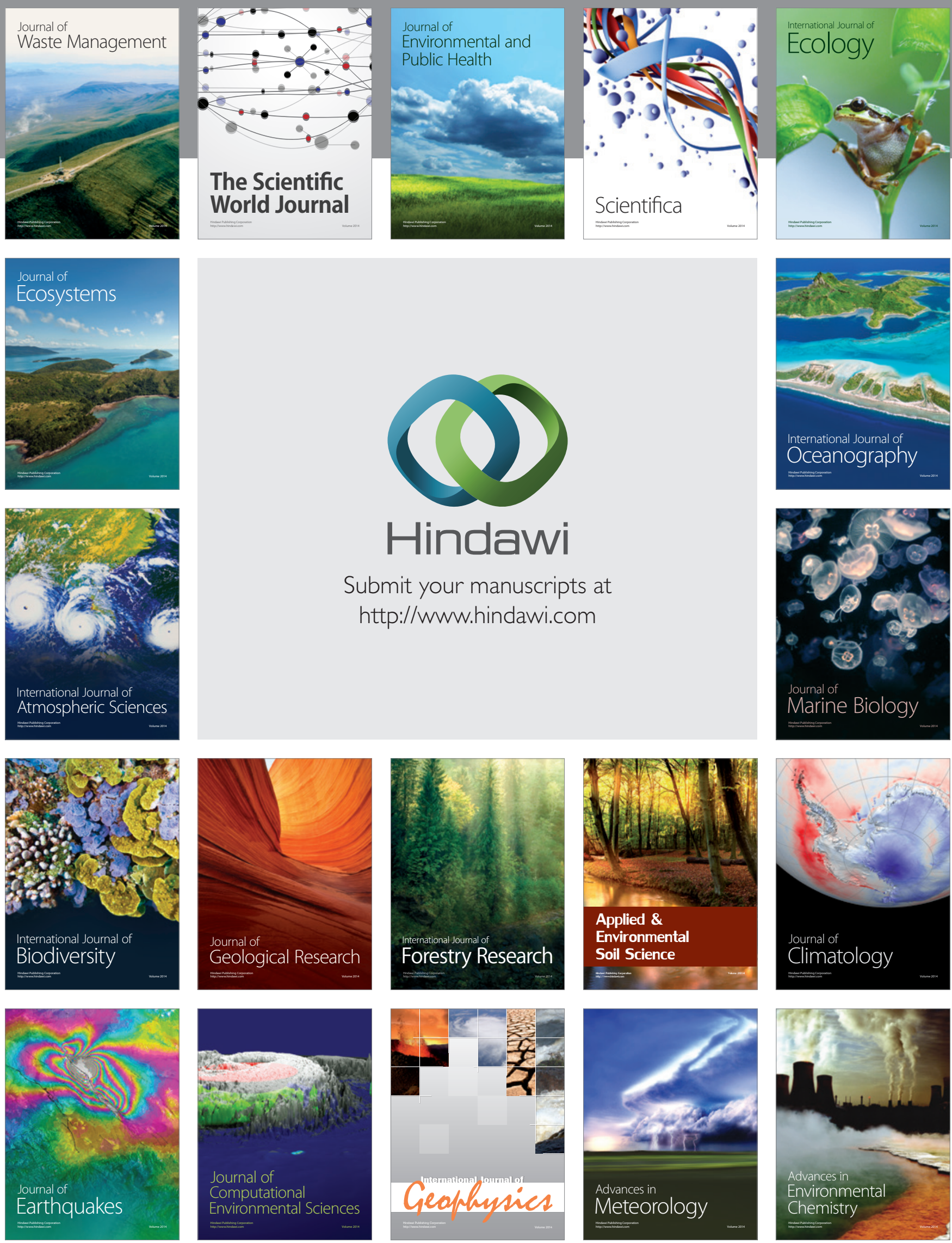